\title{
Remote Preconditioning as a Novel „Conditioning“ Approach to Repair the Broken Heart: Potential Mechanisms and Clinical Applications
}

\author{
T. RAVINGEROVA ${ }^{1}$, V. FARKASOVA ${ }^{1}$, L. GRIECSOVA ${ }^{1}$, S. CARNICKA $^{1}$, \\ M. MURARIKOVA ${ }^{1}$, E. BARLAKA ${ }^{2}$, F. KOLAR ${ }^{3}$, M. BARTEKOVA ${ }^{1}$, L. LONEK ${ }^{1}$, \\ J. SLEZAK ${ }^{1}$, A. LAZOU ${ }^{2}$
}

${ }^{1}$ Institute for Heart Research, Slovak Academy of Sciences, Bratislava, Slovakia, ${ }^{2}$ School of Biology, Aristotle University of Thessaloniki, Thessaloniki, Greece, ${ }^{3}$ Institute of Physiology of the Czech Academy of Sciences, Prague, Czech Republic

Received June 1, 2016

Accepted June 15, 2016

\section{Summary}

Remote ischemic preconditioning (RIPC) is a novel strategy of protection against ischemia-reperfusion (IR) injury in the heart (and/or other organs) by brief episodes of non-lethal IR in a distant organ/tissue. Importantly, RIPC can be induced noninvasively by limitation of blood flow in the extremity implying the applicability of this method in clinical situations. RIPC (and its delayed phase) is a form of relatively short-term adaptation to ischemia, similar to ischemic PC, and likely they both share triggering mechanisms, whereas mediators and end-effectors may differ. It is hypothesized that communication between the signals triggered in the remote organs and protection in the target organ may be mediated through substances released from the preconditioned organ and transported via the circulation (humoral pathways), by neural pathways and/or via systemic anti-inflammatory and antiapoptotic response to short ischemic bouts. Identification of molecules involved in RIPC cascades may have therapeutic and diagnostic implications in the management of myocardial ischemia. Elucidation of the mechanisms of endogenous cardioprotection triggered in the remote organ could lead to the development of diverse pharmacological RIPC mimetics. In the present article, the authors provide a short overview of RIPC-induced protection, proposed underlying mechanisms and factors modulating RIPC as a promising cardioprotective strategy.

\section{Key words}

Ischemia/reperfusion - Remote preconditioning - Innate cardioprotection

\section{Corresponding author}

T. Ravingerová, Institute for Heart Research, Slovak Academy of Sciences, P.O. BOX 104, Dúbravská cesta 9, 840 05, Bratislava, Slovak Republic. E-mail: usrdravi@savba.sk

\section{Introduction}

Ischemic preconditioning (IPC) is a very robust form of cardiac adaptation observed in all animal species including humans. Unfortunately, due to technical reasons (chest opening to get access to coronary arteries) and short-term duration, its clinical application is limited to planned interventions, such as primary percutaneous coronary intervention (PCI) or coronary artery bypass grafting surgery (CABG) (Wu et al. 2000, Hausenloy and Yellon 2008).

On the other hand, other conditioning intervention may also confer efficient cardioprotection against ischemia/reperfusion (IR) injury - a strategy introduced by Przyklenk et al. (1993) and termed remote IPC (RIPC). In this study, the authors found that short ischemic episodes of the circumflex branch of left coronary artery reduced the size of infarction induced by occlusion of left anterior descending (LAD) branch of 
coronary artery. In another study by McClanahan et al. (1993) it was demonstrated that occlusion and reperfusion of renal artery in rabbits reduced the size of myocardial infarction. Further research supported the hypothesis that the phenomenon of RIPC can be induced by ischemia of distant organs/tissues (either cardiac or noncardiac), such as small intestine (Gho et al. 1996), kidney (Weinbrenner et al. 2004) and other organs, and evokes systemic protection against acute IR injury (Przyklenk and Kloner 1998). Moreover, interorgan communication afforded protection against IR in different organs and not only in the heart (Hausenloy and Yellon 2008). Thus, it became evident that RIPC may represent a general phenomenon of distant cardioprotection.

However, these methods were still invasive. Finally, important study by Birnbaum et al. (1997) demonstrated that brief limitation of blood flow in the hind limb muscle in rabbits performed prior to longer lasting occlusion of coronary artery reduced the size of myocardial infarction by $65 \%$. Furthemore, Oxman et al. (1997) induced RIPC on rat hind limb by means of tourniqet, which efficiency was further confirmed in experiments in pigs (Kharbanda et al. 2002). Most importantly, Kharbanda et al. (2001) applied RIPC protocol in humans using pressure cuff (placed on the upper extremity), and three cycles of 5-min inflation $(200 \mathrm{~mm} \mathrm{Hg}) / 5-\mathrm{min}$ deflation successfully attenuated IR-induced endothelial dysfunction in forearm blood vessels (assessed as an improved post-IR forearm blood flow in response to acetylcholine). Later on, protocol of RIPC performed on limbs was termed „limb ischemic preconditioning“ (LIPC) (Wu et al. 2011). This protocol of RIPC is being used until now both, in clinical situations and in animal experiments.

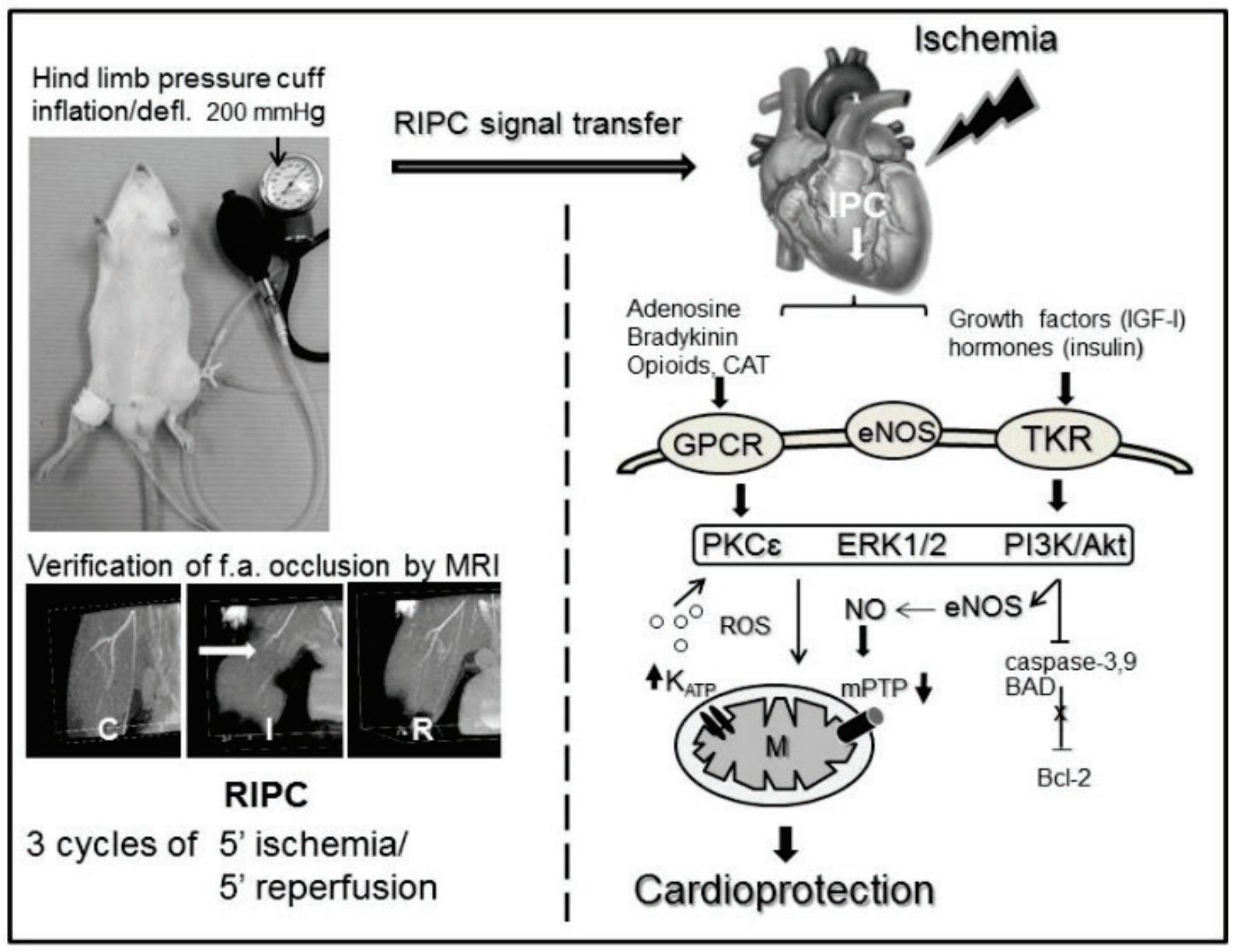

Fig. 1. Remote ischemic preconditioning applied on hind limb of rat and induction of cardioprotection in a distant organ (heart) exposed to ischemia. RIPC - remote ischemic preconditioning, MRI - magnetic resonance image. GPCR - G proteins-coupled receptors, eNOS endothelial NO synthase, TKR - receptors with tyrosine kinase activity, PKC $\varepsilon$ - protein kinase C $\varepsilon$, ERK1/2 - extracellular signal regulated kinases, PI3K/Akt - phosphatidylinositol-3-kinase/protein kinase B (Akt), ROS - reactive oxygen species, $\mathrm{K}_{\text {ATP }}$ - mitochondrial ATP-dependent potassium channels, mPTP - mitochondrial permeability transition pore, BAD, Bcl-2 - pro/antiapoptotic proteins. 
The major advantage of limb RIPC, compared with other strategies of endogenous cardioprotection, appeared to be the possibility to attenuate ischemic injury noninvasively using a standard blood pressure cuff placed on the upper or lower limb. Figure 1 illustrates application of RIPC on right hind limb of rat, where verification of femoral artery occlusion was confirmed by magnetic resonance technique. Günaydin et al. (2000) provided biochemical evidence (reduced cellular enzyme release) that RIPC applied on the upper limb in patients undergoing coronary artery surgery increased ischemic tolerance in the heart and protected the myocardium by enhancing anaerobic glycolysis during cardiac IR. This observation represented an important breakthrough in the clinical applicability of the preconditioning phenomenon. Additionally, it was shown that transient limb ischemia before PCI (stenting) led to a reduction in adverse cardiac events in a group of RIPC patients compared with control subjects who experienced adverse side effects (Hoole et al. 2009).

Since initial clinical trials in this area focused on the application of RIPC in ischemic cardiac disease, the present article briefly reviews cardioprotection induced by RIPC, the underlying mechanisms, and the factors modulating effectiveness of RIPC.

\section{Potential mechanisms, phases and transfer of RIPC effect}

Similar to other forms of preconditioning, RIPC also exerts a biphasic phenotype, as confirmed in all organ systems in animal models and in recent human studies (Tapuria et al. 2008). The 'first window' cardioprotection that starts within 5-30 min after the final cycle of RIPC is known to be mediated by modification of existing proteins and completely wanes within $3 \mathrm{~h}$. On the other hand, RIPC stimuli simultaneously initiate a complex genomic and proteomic response that is executed during the late phase of protection that reappears $24 \mathrm{~h}$ after initial stimulus and persists during three to four days, sometimes even more. This 'second window' of protection is attributed to the activation of transcriptional regulation, protein translation and posttranslational changes of newly synthesized proteins, e.g. those with antioxidative properties (Kageyama et al. 2015) resulting in longer-lasting protection.

Generally, it is accepted that RIPC represents a complex cascade of initial triggers activated or generated in the remote tissue, mediators of communication between the remote site and the target organ (heart), and end-effectors responsible for induction of the protective phenotype in the myocardium (Przyklenk and Whittaker 2011).

The aspect of RIPC-induced interorgan communication is still not completely elucidated. Several pathways are proposed to transfer protective signal from the distant organ to the heart: humoral pathways, neural pathways or by means of systemic response (Bousselmi et al. 2014).

According to the humoral hypothesis, endogenous substances released from the conditioned organ/tissue are transferred via circulation to the target organs, where they activate the respective receptors and trigger cascade of IPC (Hausenloy and Yellon 2008). However, the precise identity of humoral RIPC mediators remains unclear (Gill et al. 2015).

Neural hypothesis was based on the findings that ganglion blockers (Gho et al. 1996, Loukogeorgakis et al. 2005), vagotomy (Lim et al. 2010) or other interventions interrupting nervous afferent or efferent pathways abolished RIPC-induced cardioprotection.

The third hypothesis implies that RIPC stimulus induces a systemic response in the organism with subsequent suppression of inflammation and apoptosis (Hausenloy and Yellon 2008), while modifying pro/antiinflammatory gene profile (up-regulation of antiinflammatory genes or suppression of inflammatory genes) (Konstantinov et al. 2004, Shimizu et al. 2010).

Currently, it is believed that transmission of the RIPC signal to the target organ is multifactorial, requiring a combination of humoral, neuronal and systemic mechanisms, and may be model-dependent (Lim et al. 2010). Recent research has revealed that such communication could be also mediated via peroxisome proliferator activated nuclear receptors (PPARs) involved in limb RIPC-induced cardioprotection (Lotz et al. 2011). Kidney-induced RIPC showed activation of signaling cascades mediated by transcription factor NFKB followed by subsequent opening of mitochondrial ATP-sensitive

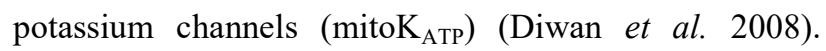
These findings confirm an important role of gene transcription in RIPC-mediated effects.

The schematic presentation of potential pathways of signal transfer from conditioned to a target organ is shown in Figure 2. The procedure of RIPC may be applied prior to ischemia (as pre-conditioning), during ischemia (as per-conditioning) or just after ischemia (as post-conditioning) (Kanoria et al. 2007, Hausenloy and Yellon 2008, Tapuria et al. 2008). 


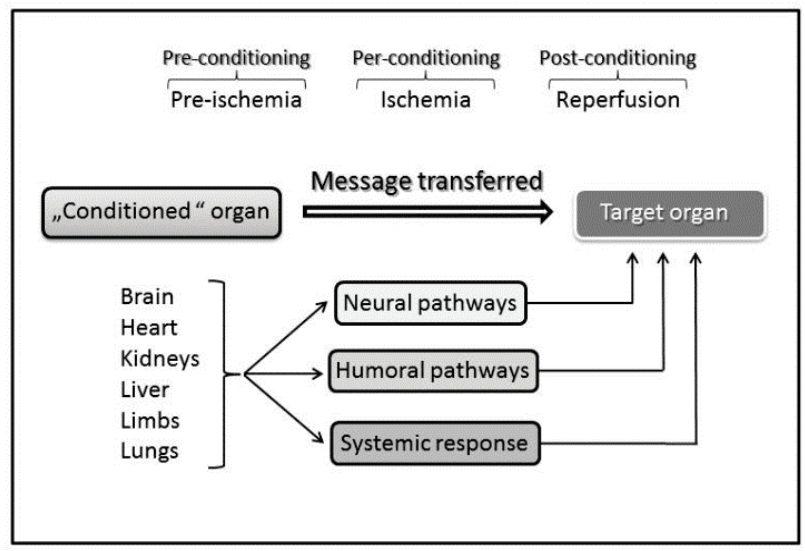

Fig. 2. Schematic presentation of remote preconditioning and pathways of protective signal transduction to distant target organs.

\section{Potential triggers of RIPC}

It is hypothesized that initial triggers of both IPC and RIPC may be universal and able to induce protection either in host organs or the organs of recipients of coronary effluent transfer (Dickson et al. 1999). The mechanisms underlying RIPC have been studied extensively, however, the exact triggering molecules involved are not completely clarified. Possible candidates involve adenosine, bradykinin-2, opioids, angiotensin-1, reactive oxygen species (ROS), noradrenaline, nitric oxide (NO), heat shock proteins (HSP) and calcitonin gene-related peptide (CGRP) (Heusch et al. 2008, Tapuria et al. 2008, Rassaf et al. 2014). These substances act through multiple receptors (mostly G-protein-coupled receptors [GPCR]) or activate downstream „survival“ pathways via non-receptor-mediated mechanisms.

\section{Potential mediators of RIPC}

RIPC triggers can activate GPCR-linked pathways that include 1,2-diacylglycerol, protein kinase $\mathrm{C}$ (PKC), mitogen-activated protein kinase (MAPK), CGRP, and transcription factors, such as NFאB (Wolfrum et al. 2002, 2005, Li et al. 2004) mediating a protective signal to an end-effector.

It is suggested that cellular signaling pathways in the conditioned organ/tissue and in the target one are similar to those involved in the mechanisms of IPC or postconditioning (IPost). A number of mediators are known to belong to these signaling cascades including PKC, NO synthase, phosphatidylinositol-3-kinase/protein kinase B (PI3K/Akt), MAP-kinases, signal transducers and activators of transcription 5 (STAT5) proteins, ROS, etc. (Hausenloy and Yellon 2008, Heusch et al. 2012, Rassaf et al. 2014). Postreceptor mechanisms also encompass cyclic guanosine monophosphate-dependent protein kinase (cGMP/PKG) pathways (Burley et al. 2007), the reperfusion injury risk kinases (RISK) pathway involving PI3K/Akt and extracellular signalregulated kinase (ERK1/2) pathway (Hausenloy and Yellon 2008), and the survivor activating factor enhancement (SAFE) pathway (Lecour et al. 2009). Opening of mitoK $\mathrm{K}_{\mathrm{ATP}}$ channels is considered to be one of the crucial mechanisms in different cardioprotective interventions coupled with an increased production of ROS activating prosurvival signaling pathways, such as PI3K/Akt, PKC $\varepsilon$, and/or glycogen synthase kinase-3 $\beta$ (Forbes et al. 2008, Matejikova et al. 2009), leading to functional recovery and infarct size limitation. Activation of mitoK $K_{\text {ATP }}$ has been also shown to be involved in the delayed effect of hind limb RIPC in rats (Wu et al. 2011). However, it remains unclear whether they act as triggers, mediators and/or end-effectors.

Some recent findings demonstrated less known mechanisms of RIPC-induced mediators of cardioprotection, such as the involvement of hypoxiainduced factor HIF-1 $\alpha$ (Albrecht et al. 2013), the role of extracellular vesicles (Giricz et al. 2014), connexin 43 phosphorylation (Brandenburger et al. 2014a) or microRNA-1 (Brandenburger et al. 2014b).

\section{Potential end-effectors of RIPC in the heart}

Impairment of mitochondrial function plays a major role in IR injury, and not surprisingly, mitochondrial modulation has been considered to be implicated in the cardioprotective effects of IPC. The fluidity of mitochondrial membranes is a biophysical property that governs cell fate toward survival or death, and is tightly bound with the regulation of diverse adaptive and/or pathological processes including IR (Ziegelhöffer et al. 2012). All aforementioned transduction systems involved in the preconditioning protection appear to converge on the mitochondria (Murphy and Steenbergen 2007). Modulation of mitochondrial function is linked to changes in mitochondrial permeability transition pore (mPTP) opening and cytochrome c release, leading to activation or inhibition of proapoptotic cascades in the cytosol (Halestrap et al. 2007). The inhibition of mPTP opening via RISK is suggested as a final common target through which the signaling pathways can protect the cell against necrosis/apoptosis (Hausenloy et al. 2004, Heusch et al. 
2008). This is in line with the study of Zhang et al. (2006), in which specific mPTP activator atractyloside abrogated IS-limiting effect of RIPC. Moreover, it has been recently shown that RIPC applied on rat hind limb improved functional and biophysical properties of cardiac mitochondria (Ferko et al. 2014). These mechanisms of RIPC-induced cardioprotection are briefly summarized in Figure 1.

\section{Potential clinical applications of remote preconditioning}

One of the first studies in humans was the study by Kharbanda et al. (2001). Since that time, numerous research teams have been investigating the effect of RIPC against acute IR under different clinical conditions. Most of the studies were designed to reveal whether RIPC was able to protect human heart against IR injury, in particular, under conditions of cardiac surgery, primary PCI or during the management of acute myocardial infarction (Lim and Hausenloy 2012). First successful application of RIPC in clinical conditions was reported by Cheung et al. (2006) in children undergoing cardiac surgery for congential heart defect, which was very often associated with high mortality of patients. These authors found that 4 cycles of 5-min RIPC by inflation/deflation of pressure cuff placed on lower extremity, prior to surgery, resulted in a reduced extent of myocardial injury (less troponin I release, lower inotropic score). Later on, Hausenloy et al. (2007) demonstrated that 3 cycles of IR were able to reduce the degree of myocardial injury (reduced troponin $\mathrm{T}$ release) in adults undergoing $\mathrm{CABG}$ surgery.

Since then, numerous studies demonstrated positive effect of RIPC applied in patients prior to CABG surgery, primary PCI (Choi et al. 2011, Ahmed et al. 2013, Zografos et al. 2014) or in patients with acute myocardial infarction (Prunier et al. 2014, White et al. 2015). However, several other studies failed to demonstrate any benefit in these patients (Rahman et al. 2010, Karuppasamy et al. 2011).

One of the last big clinical trials was ERICCA study (Hausenloy et al. 2015), which recent results failed to demonstrate positive effects of RIPC in patients that underwent $\mathrm{CABG}$. Another clinical trial (Meybohm et al. 2015) also did not reveal any relevant benefit of RIPC in patients after cardiac surgery. However, all aformentioned studies were focused on clinical outcomes, and were not exploring molecular mechanisms of RIPC in humans (Moscarelli et al. 2015). To better understanding the controversies in the results, it will be necessary to consider the elucidation of molecular basis of RIPC in animals and humans.

\section{Factors modulating the effectiveness of RIPC}

RIPC was originally characterized in young and healthy experimental animals. In these settings, coronary circulation, per se, is intact and is only subject to controlled occlusion and reperfusion by external or internal devices. This model is not adequate for the studies of RIPC in humans who experience myocardial infarction usually in elder age, and coronary circulation of these patients is influenced by pre-existing atherosclerotic lesions. Ischemic heart disease is characterized by a certain level of limitation of coronary circulation, which is an essential cause of ischemic injury (Ravingerova et al. 2012). On the other hand, cycles of coronary occlusion and reperfusion that occur spontaneously, often before sustained ischemia, may thus act as a stimulus of cardioprotection. The state of coronary circulation is, therefore, a major determinant of cardioprotection, and so called pre-infarction angina pectoris is considered as a clinical equivalent of IPC (Abete et al. 1997). However, coronary circulation may be affected by numerous comorbidities. Risk factors for cardiovascular diseases, such as stress, chronically elevated blood pressure and metabolic disorders, have a negative impact on the heart exposed to ischemia and may aggravate lethal injury (i.e. myocardial infarction). Moreover, it has been shown that the protective effect of IPC, postconditioning and RIPC is suppressed by comorbidities, such as hypercholesterolemia, hyperglycemia, hypertension, cardiac hypertrophy, aging, obesity, as well as by comedications (Ferdinandy et al. 2014). However, pathologically altered myocardium does not completely lose its adaptive potential. Thus, no loss of the efficacy of IPC was shown in middle-aged and older rabbits in vivo (Przyklenk et al. 2001). The impact of aging on the efficiency of RIPC is not yet completely elucidated, and the results are controversial. While RIPC failed to protect the heart of neonatal rabbits against IR, in adult animals, IS-limiting effect of RIPC was obvious (Schmidt et al. 2014). More information about agedependency of effects of RIPC was gained from the clinical studies. Positive effects of limb RIPC applied prior to cardiac surgery in children have been observed in several studies (Cheung et al. 2006, Zhou et al. 2010), however, a lack of RIPC effects was also reported (Pavione et al. 2012, McCrindle et al. 2014). On the other 
hand, although in elder patients the benefit of RIPC was often absent (Meybohm et al. 2015), especially in those individuals with diabetes mellitus (Xu et al. 2014), other authors reported positive effects of different protocols of RIPC in adult and old patients when applied prior to coronary interventions (Kono et al. 2014, White et al. 2015). This may indicate the possibility of reactivating reduced preconditioning potential by modification of the intensity of the preconditioning stimulus or by use of an alternative mode of cardiac adaptation.

\section{Conclusions}

Despite controversial outcomes of some clinical trials, RIPC has shown promising results in recent experimental studies indicating its potential to protect the ischemic heart in clinical practice. The main advantage of this strategy is that it appears to be an effective, safe, noninvasive, easily applicable and cost-effective cardioprotective tool against IR injury in scenarios in which ischemic damage is suspected but the occurence of myocardial infarction is unpredictable. Identification of molecules involved in RIPC cascades may have therapeutic and diagnostic implications in the management of acute myocardial ischemia and could lead to the development of diverse pharmacological RIPC mimetics in accordance with the stage of ischemic heart disease, planned intervention and/or prospective comorbidities.

\section{Conflict of Interest}

There is no conflict of interest.

\section{Acknowledgements}

This study was supported by grants VEGA SR 2/0201/15, 2/0021/15, 2/0061/16, APVV-0102-11, APVV-15-0376 and APVV-0241-11.

\section{References}

ABETE P, FERRARA N, CACCIATORE F, MADRID A, BIANCO S, CALABRESE C, NAPOLI C, SCOGNAMIGLIO P, BOLLELLA O, CIOPPA A, LONGOBARDI G, RENGO F: Angina-induced protection against myocardial infarction in adult and elderly patients: a loss of preconditioning mechanism in the aging heart? J Am Coll Cardiol 30: 947-954, 1997.

AHMED RM, MOHAMED EL-HA, ASHRAF M, MAITHILI S, NABIL F, RAMI R, MOHAMED TI: Effect of remote ischemic preconditioning on serum troponin $\mathrm{T}$ level following elective percutaneous coronary intervention. Catheter Cardiovasc Interv 82: E647-E653, 2013.

ALBRECHT M, ZITTA K, BEIN B, WENNEMUTH G, BROCH O, RENNER J, SCHUETT T, LAUER F, MAAHS D, HUMMITZSCH L, CREMER J, ZACHAROWSKI K, MEYBOHM P: Remote ischemic preconditioning regulates HIF-1alpha levels, apoptosis and inflammation in heart tissue of cardiosurgical patients: a pilot experimental study. Basic Res Cardiol 108: 314, 2013.

BALAKUMAR P, SINGH H, SINGH M, ANAND-SRIVASTAVA MB: The impairment of preconditioning-mediated cardioprotection in pathological conditions. Pharmacol Res 60: 18-23, 2009.

BIRNBAUM Y, HALE SL, KLONER RA: Ischemic preconditioning at a distance: reduction of myocardial infarct size by partial reduction of blood supply combined with rapid stimulation of the gastrocnemius muscle in the rabbit. Circulation 96: 1641-1646, 1997.

BOUSSELMI R, LEBBI MA, FERJANI M: Myocardial ischemic conditioning: physiological aspects and clinical applications in cardiac surgery. J Saudi Heart Assoc 26: 93-100, 2014.

BRANDENBURGER T, HUHN R, GALAS A, PANNEN BH, KEITEL V, BARTHEL F, BAUER I, HEINEN A: Remote ischemic preconditioning preserves Connexin 43 phosphorylation in the rat heart in vivo. $J$ Transl Med 12: $228,2014 \mathrm{a}$.

BRANDENBURGER T, GRIEVINK H, HEINEN N, BARTHEL F, HUHN R, STACHULETZ F, KOHNS M, PANNEN B, BAUER I: Effects of remote ischemic preconditioning and myocardial ischemia on microRNA-1 expression in the rat heart in vivo. Shock 42: 234-238, $2014 \mathrm{~b}$.

BURLEY DS, FERDINANDY P, BAXTER GF: Cyclic GMP and protein kinase-G in myocardial ischaemiareperfusion: opportunities and obstacles for survival signaling. Br J Pharmacol 152: 855-869, 2007. 
CHEUNG MM, KHARBANDA RK, KONSTANTINOV IE, SHIMIZU M, FRNDOVA H, LI J, HOLTBY HM, COX PN, SMALLHORN JF, VAN ARSDELL GS, REDINGTON AN: Randomized controlled trial of the effects of remote ischemic preconditioning on children undergoing cardiac surgery: first clinical application in humans. J Am Coll Cardiol 47: 2277-2282, 2006.

CHOI YS, SHIM JK, KIM JC, KANG KS, SEO YH, AHN KR, KWAK YL: Effect of remote ischemic preconditioning on renal dysfunction after complex valvular heart surgery: a randomized controlled trial. J Thorac Cardiovasc Surg 142: 148-154, 2011.

DICKSON EW, LORBAR M, PORCARO WA, FENTON RA, REINHARDT CP, GYSEMBERGH A, PRZYKLENK K: Rabbit heart can be "preconditioned" via transfer of coronary effluent. Am J Physiol 277: H2451-H2457, 1999.

DIWAN V, KANT R, JAGGI AS, SINGH N, SINGH D: Signal mechanism activated by erythropoietin preconditioning and remote renal preconditioning-induced cardioprotection. Mol Cell Biochem 315: 195-201, 2008.

FERDINANDY P, HAUSENLOY D, HEUSCH G, BAXTER GF, SCHULZ R: Interaction of risk factors, comorbidities, and comedications with ischemia/reperfusion injury and cardioprotection by preconditioning, postconditioning, and remote conditioning. Pharmacol Rev 66: 1142-1174, 2014.

FERKO M, KANCÍROVÁ I, JAŠOVÁ M, ČARNICKÁ S, MURÁRIKOVÁ M, WACZULÍKOVÁ I, SUMBALOVÁ Z, KUCHARSKÁ J, ULIČNÁ O, RAVINGEROVÁ T, ZIEGELHÖFFER A: Remote ischemic preconditioning of the heart: protective responses in functional and biophysical properties of cardiac mitochondria. Physiol Res 63 (Suppl 4): S469-S478, 2014.

FORBES RA, STEENBERGEN C, MURPHY E: Diazoxide-induced cardioprotection requires signaling through a redox-sensitive mechanism. Circ Res 88: 802-809, 2008.

GHO BC, SCHOEMAKER RG, VAN DEN DOEL MA, DUNCKER DJ, VERDOUW PD: Myocardial protection by brief ischemia in noncardiac tissue. Circulation 94: 2193-2200, 1996.

GILL R, KURIAKOSE R, GERTZ ZM, SALLOUM FN, XI L, KUKREJA RC: Remote ischemic preconditioning for myocardial protection: update on mechanisms and clinical relevance. Mol Cell Biochem 402: 41-49, 2015.

GIRICZ Z, VARGA ZV, BARANYAI T, SIPOS P, PALOCZI K, KITTEL A, BUZAS EI, FERDINANDY P: Cardioprotection by remote ischemic preconditioning of the rat heart is mediated by extracellular vesicles. J Mol Cell Cardiol 68: 75-78, 2014.

GÜNAYDIN B, CAKICI I, SONCUL H, KALAYCIOGLU S, CEVIK C, SANCAK B, KANZIK I, KARADENIZLI $\mathrm{Y}$ : Does remote organ ischemia trigger cardiac preconditioning during coronary artery surgery? Pharm Res $\mathbf{4 1}$ : 493-496, 2000.

HALESTRAP AP, CLARKE SJ, KHALIULIN I: The role of mitochondria in protection of the heart by preconditioning. Biochim Biophys Acta 1767: 1007-1031, 2007.

HAUSENLOY DJ, YELLON DM: Remote ischaemic preconditioning: underlying mechanisms and clinical application. Cardiovasc Res 79: 377-386, 2008.

HAUSENLOY DJ, YELLON DM, MANI-BABU S, DUCHEN MR: Preconditioning protects by inhibiting the mitochondrial permeability transition. Am J Physiol Heart Circ Physiol 287: 841-849, 2004.

HAUSENLOY DJ, MWAMURE PK, VENUGOPAL V, HARRIS J, BARNARD M, GRUNDY E, ASHLEY E, VICHARE S, Di SALVO C, KOLVEKAR S, HAYWARD M, KEOGH B, MACALLISTER RJ, YELLON DM: Effect of remote ischaemic preconditioning on myocardial injury in patients undergoing coronary artery bypass graft surgery: a randomised controlled trial. Lancet 370: 575-579, 2007.

HAUSENLOY DJ, LECOUR S, YELLON DM: Reperfusion injury salvage kinase and survivor activating factor enhancement prosurvival signaling pathways in ischemic postconditioning: two sides of the same coin. Antioxid Redox Signal 14: 893-907, 2011.

HAUSENLOY DJ, CANDILIO L, EVANS R, ARITI C, JENKINS DP, KOLVEKAR S, KNIGHT R, KUNST G, LAING C, NICHOLAS J, PEPPER J, ROBERTSON S, XENOU M, CLAYTON T, YELLON DM; ERICCA TRIAL INVESTIGATORS: Remote ischemic preconditioning and outcomes of cardiac surgery. $N$ Engl $J$ Med 373: 1408-1417, 2015.

HEUSCH G, BOENGLER K, SCHULZ R: Cardioprotection: nitric oxide, protein kinases, and mitochondria. Circulation 118: 1915-1919, 2008. 
HEUSCH G, MUSIOLIK J, KOTTENBERG E, PETERS J, JAKOB H, THIELMANN M: STAT5 activation and cardioprotection by remote ischemic preconditioning in humans. Circ Res 110: 111-115, 2012.

HOOLE SP, HECK PM, SHARPLES L, KHAN SN, DUEHMKE R, DENSEM CG, CLARKE SC, SHAPIRO LM, SCHOFIELD PM, O'SULLIVAN M, DUTKA DP: Cardiac Remote Ischemic Preconditioning in Coronary Stenting (CRISP Stent) Study: a prospective, randomized control trial. Circulation 119: 820-827, 2009.

KAGEYAMA S, HATA K, TANAKA H, HIRAO H, KUBOTA T, OKAMURA Y, IWAISAKO K, TAKADA Y, UEMOTO S: Intestinal ischemic preconditioning ameliorates hepatic ischemia/reperfusion injury in rats: role of heme oxygenase 1 in the second window of protection. Liver Transpl 21: 112-122, 2015.

KANORIA S, JALAN R, SEIFALIAN AM, WILLIAMS R, DAVIDSON BR: Protocols and mechanisms for remote ischemic preconditioning: a novel method for reducing ischemia reperfusion injury. Transplantation 84: 445-458, 2007.

KARUPPASAMY P, CHAUBEY S, DEW T, MUSTO R, SHERWOOD R, DESAI J, JOHN L, SHAH AM, MARBER MS, KUNST G: Remote intermittent ischemia before coronary artery bypass graft surgery: a strategy to reduce injury and inflammation? Basic Res Cardiol 106: 511-519, 2011.

KHARBANDA RK, PETERS M, WALTON B, KATTENHORN M, MULLEN M, KLEIN N, VALLANCE P, DEANFIELD J, MACALLISTER R: Ischemic preconditioning prevents endothelial injury and systemic neutrophil activation during ischemia-reperfusion in humans in vivo. Circulation 103: 1624-1630, 2001.

KHARBANDA RK, MORTENSEN UM, WHITE PA, KRISTIANSEN SB, SCHMIDT MR, HOSCHTITZKY JA, VOGEL M, SORENSEN K, REDINGTON AN, MACALLISTER R: Transient limb ischemia induces remote ischemic preconditioning in vivo. Circulation 106: 2881-2883, 2002.

KONO Y, FUKUDA S, HANATANI A, NAKANISHI K, OTSUKA K, TAGUCHI H, SHIMADA K: Remote ischemic conditioning improves coronary microcirculation in healthy subjects and patients with heart failure. Drug Des Devel Ther 8: 1175-1181, 2014.

KONSTANTINOV IE, ARAB S, KHARBANDA RK, LI J, CHEUNG MM, CHEREPANOV V, DOWNEY GP, LIU PP, CUKERMAN E, COLES JG, REDINGTON AN: The remote ischemic preconditioning stimulus modifies inflammatory gene expression in humans. Physiol Genomics 19: 143-150, 2004.

LECOUR S: Activation of the protective Survivor Activating Factor Enhancement (SAFE) pathway against reperfusion injury: does it go beyond the RISK pathway? J Mol Cell Cardiol 47: 32-40, 2009.

LI G, LABRUTO F, SIRSJO A, CHEN F, VAAGE J, VALEN G: Myocardial protection by remote preconditioning: the role of nuclear factor kappa-B p105 and inducible nitric oxide synthase. Eur J Cardiothorac Surg 26: 968-973, 2004.

LIM SY, HAUSENLOY DJ: Remote ischemic conditioning: from bench to bedside. Front Physiol 3: $27,2012$.

LIM SY, YELLON DM, HAUSENLOY DJ: The neural and humoral pathways in remote limb ischemic preconditioning. Basic Res Cardiol 105: 651-655, 2010.

LOTZ C, LAZARIOTTO M, REDEL A, SMUL TM, STUMPNER J, BLOMEYER C, TISCHER-ZEITZ T, SCHMIDT J, POCIEJ J, ROEWER N, KEHL F, LANGE M: Activation of peroxisome-proliferator-activated receptors $\alpha$ and $\gamma$ mediates remote ischemic preconditioning against myocardial infarction in vivo. Exp Biol Med 236: 113-122, 2011.

LOUKOGEORGAKIS SP, PANAGIOTIDOU AT, BROADHEAD MW, DONALD A, DEANFIELD JE, MACALLISTER RJ: Remote ischemic preconditioning provides early and late protection against endothelial ischemia-reperfusion injury in humans: role of the autonomic nervous system. J Am Coll Cardiol 46: 450-456, 2005.

MATEJÍKOVÁ J, KUCHARSKÁ J, PINTÉROVÁ M, PANCZA D, RAVINGEROVÁ T: Protection against ischemiainduced ventricular arrhythmias and myocardial dysfunction conferred by preconditioning in the rat heart: involvement of mitochondrial K(ATP) channels and reactive oxygen species. Physiol Res 58: 9-19, 2009.

MCCLANAHAN T, NAO B, WOLKE L, MARTIN BJ, MEZT TE: Brief renal occlusion and reperfusion reduces myocardial infarct size in rabbits. FASEB J 7: A18, 1993. 
MCCRINDLE BW, CLARIZIA NA, KHAIKIN S, HOLTBY HM, MANLHIOT C, SCHWARTZ SM, CALDARONE CA, COLES JG, VAN ARSDELL GS, SCHERER SW, REDINGTON AN: Remote ischemic preconditioning in children undergoing cardiac surgery with cardiopulmonary bypass: a single-center double-blinded randomized trial. J Am Heart Assoc 3: e000964, 2014.

MEYBOHM P, BEIN B, BROSTEANU O, CREMER J, GRUENEWALD M, STOPPE C, COBURN M, SCHAELTE G, BÖNING A, NIEMANN B, ROESNER J, KLETZIN F, STROUHAL U, REYHER C, LAUFENBERGFELDMANN R, FERNER M, BRANDES IF, BAUER M, STEHR SN, KORTGEN A, WITTMANN M, BAUMGARTEN G, MEYER-TRESCHAN T, KIENBAUM P, HERINGLAKE M, SCHÖN J, SANDER M, TRESKATSCH S, SMUL T, WOLWENDER E, SCHILLING T, FUERNAU G, HASENCLEVER D, ZACHAROWSKI K; RIPHEART STUDY COLLABORATORS: A multicenter trial of remote ischemic preconditioning for heart surgery. N Engl J Med 373: 1397-1407, 2015.

MOSCARELLI M, ANGELINI GD, SULEIMAN S, FIORENTINO F, PUNJABI PP: Remote ischaemic preconditioning: is it a flag on the field? Perfusion 30: 438-447, 2015.

MURPHY E, STEENBERGEN C: Preconditioning: the mitochondrial connection. Ann Rev Physiol 69: 51-67, 2007.

OXMAN T, ARAD M, KLEIN R, AVAZOV N, RABINOWITZ B: Limb ischemia preconditions the heart against reperfusion tachyarrhythmia. Am J Physiol 273: H1707-H1712, 1997.

PAVIONE MA, CARMONA F, DE CASTRO M, CARLOTTI AP: Late remote ischemic preconditioning in children undergoing cardiopulmonary bypass: a randomized controlled trial. J Thorac Cardiovasc Surg 144: 178-183, 2012.

PRUNIER F, ANGOULVANT D, SAINT ETIENNE C, VERMES E, GILARD M, PIOT C, ROUBILLE F, ELBAZ M, OVIZE M, BIÈRE L, JEANNETEAU J, DELÉPINE S, BENARD T, ABI-KHALIL W, FURBER A: The RIPOST-MI study, assessing remote ischemic perconditioning alone or in combination with local ischemic postconditioning in ST-segment elevation myocardial infarction. Basic Res Cardiol 109: 400, 2014.

PRZYKLENK K, KLONER RA: Ischemic preconditioning: exploring the paradox. Prog Cardiovasc Dis 40: 517-547, 1998.

PRZYKLENK K, WHITTAKER P: Remote ischemic preconditioning: current knowledge, unresolved questions, and future priorities. J Cardiovasc Pharmacol Ther 16: 255-259, 2011.

PRZYKLENK K, BAUER B, OVIZE M, KLONER RA, WHITTAKER P: Regional ischemic 'preconditioning' protects remote virgin myocardium from subsequent sustained coronary occlusion. Circulation 87: 893-899, 1993.

PRZYKLENK K, LI G, WHITTAKER P: No loss on the in vivo efficacy of ischemic preconditioning in the middle aged and old rabbits. J Am Coll Cardiol 38: 1741-1747, 2001.

RAHMAN IA, MASCARO JG, STEEDS RP, FRENNEAUX MP, NIGHTINGALE P, GOSLING P, TOWNSEND P, TOWNEND JN, GREEN D, BONSER RS: Remote ischemic preconditioning in human coronary artery bypass surgery: from promise to disappointment? Circulation 122: S53- S59, 2010.

RASSAF T, TOTZECK M, HENDGEN-COTTA UB, SHIVA S, HEUSCH G, KELM M: Circulating nitrite contributes to cardioprotection by remote ischemic preconditioning. Circ Res 114: 1601-1610, 2014.

RAVINGEROVA T, CARNICKA S, NEMCEKOVA M, LEDVÉNYIOVÁ V, ADAMEOVÁ A, KHANDELWAL VK, ZÁLEŠÁK M, KOLÁ̌̌ F: The impact of lifestyle-related risk factors on cardiac response to ischemia and possibilities to restore impaired ischemic tolerance. Physiol Res 61 (Suppl 2): S1-S10, 2012.

SCHMIDT MR, STØTTRUP NB, MICHELSEN MM, CONTRACTOR H, SØRENSEN KE, KHARBANDA RK, REDINGTON AN, BØTKER HE: Remote ischemic preconditioning impairs ventricular function and increases infarct size after prolonged ischemia in the isolated neonatal rabbit heart. J Thorac Cardiovasc Surg 147: 1049-1055, 2014.

SHIMIZU M, SAXENA P, KONSTANTINOV IE, CHEREPANOV V, CHEUNG MM, WEARDEN P, ZHANGDONG H, SCHMIDT M, DOWNEY GP, REDINGTON AN: Remote ischemic preconditioning decreases adhesion and selectively modifies functional responses of human neutrophils. J Surg Res 158: $155-161,2010$. 
TAPURIA N, KUMAR Y, HABIB MM, ABU AMARA M, SEIFALIAN AM, DAVIDSON BR: Remote ischemic preconditioning: a novel protective method from ischemia reperfusion injury - a review. J Surg Res 150: 304-330, 2008.

WEINBRENNER C, SCHULZE F, SARVARY L, STRASSER RH: Remote preconditioning by infrarenal aortic occlusion is operative via delta1-opioid receptors and free radicals in vivo in the rat heart. Cardiovasc Res 61 : 591-599, 2004.

WHITE SK, FROHLICH GM, SADO DM, MAESTRINI V, FONTANA M, TREIBEL TA, TEHRANI S, FLETT AS, MEIER P, ARITI C, DAVIES JR, MOON JC, YELLON DM, HAUSENLOY DJ: Remote ischemic conditioning reduces myocardial infarct size and edema in patients with ST-segment elevation myocardial infarction. JACC Cardiovasc Interv 8: 178-188, 2015.

WOLFRUM S, SCHNEIDER K, HEIDBREDER M, NIENSTEDT J, DOMINIAK P, DENDORFER A: Remote preconditioning protects the heart by activating myocardial PKCepsilon-isoform. Cardiovasc Res 55: 583-589, 2002.

WOLFRUM S, NIENSTEDT J, HEIDBREDER M, SCHNEIDER K, DOMINIAK P, DENDORFER A: Calcitonin gene related peptide mediates cardioprotection by remote preconditioning. Regul Pept 127: 217-224, 2005.

WU YN, YU H, ZHU XH, YUAN HJ, KANG Y, JIAO JJ, GAO WZ, LIU YX, LOU JS: Noninvasive delayed limb ischemic preconditioning attenuates myocardial ischemia-reperfusion injury in rats by a mitochondrial K(ATP) channel-dependent mechanism. Physiol Res 60: 271-279, 2011.

WU ZK, TARKKA MR, PEHKONEN E, KAUKINEN L, HONKONEN EL, KAUKINEN S: Ischaemic preconditioning has a beneficial effect on left ventricular haemodynamic function after a coronary artery biopass grafting operation. Scand Cardiovasc J 34: 247-253, 2000.

XU X, ZHOU Y, LUO S, ZHANG W, ZHAO Y, YU M, MA Q, GAO F, SHEN H, ZHANG J: Effect of remote ischemic preconditioning in the elderly patients with coronary artery disease with diabetes mellitus undergoing elective drug-eluting stent implantation. Angiology 65: 660-666, 2014.

ZHANG SZ, WANG NF, XU J, GAO Q, LIN GH, BRUCE IC, XIA Q: Kappa-opioid receptors mediate cardioprotection by remote preconditioning. Anesthesiology 105: 550-556, 2006.

ZHOU W, ZENG D, CHEN R, LIU J, YANG G, LIU P, ZHOU X: Limb ischemic preconditioning reduces heart and lung injury after an open heart operation in infants. Pediatr Cardiol 31: 22-29, 2010.

ZIEGELHÖFFER A, WACZULÍKOVÁ I, FERKO M, ŠIKUROVÁ L, MUJKOŠOVÁ J, RAVINGEROVÁ T: Involvement of membrane fluidity in endogenous protective processes running on subcellular membrane systems of the rat heart. Physiol Res 61 (Suppl 2): S11-S21, 2012.

ZOGRAFOS TA, KATRITSIS GD, TSIAFOUTIS I, BOURBOULIS N, KATSIVAS A, KATRITSIS DG: Effect of one-cycle remote ischemic preconditioning to reduce myocardial injury during percutaneous coronary intervention. Am J Cardiol 113: 2013-2017, 2014. 